\title{
Outbreak of Febrile Illness Associated with E.C.H.O. Virus Type 5 in a Maternity Unit in Singapore
}

\author{
L. J. GERMAN,* M.D., M.R.C.o.G. ; A. W. MCCRACKEN, † M.B., M.C.PATH., D.C.P., D.T.M.\&H. \\ K. MCD. WILKIE, F.I.M.L.T.
}

Brit. med. F., 1968, 1, 742-744

Though there have been many reports on sporadic illness due to E.C.H.O. viruses (Kibrick, 1964), relatively few epidemics have been attributed to this group of viruses. E.C.H.O. virus type 5 is one of 30 known serotypes; it has been associated with one small outbreak which involved six newborn infants (Hart et al., 1962) and with a few instances of sporadic disease (Davis and Melnick, 1958; Selwyn and Howitt, 1962). This paper describes an epidemic illness which appeared to be caused by E.C.H.O. virus type 5 and which clinically affected 56 newborn infants and eight adults. A further 10 infants and seven mothers had serological evidence of subclinical infection.

The outbreak occurred in the maternity unit at the Royal Air Force Hospital, Changi, which is situated in the eastern tip of Singapore. During 1966826 deliveries took place in this
A faint pink macular rash was observed in 20 infants $(36 \%)$. The rash was most pronounced on the limbs and buttocks, but was also present on the trunk and face. It usually appeared 24 to 36 hours after the onset of pyrexia and subsided completely in 48 hours without desquamation.

Seventeen infants $(30 \%)$ developed abnormal stools during the illness: 13 had very loose offensive stools and four others passed blood and mucus on several occasions. No enteropathogenic bacteria were isolated from any of these infants. Half of the infants were bottle-fed and half were breast-fed, but it is the practice in this maternity unit to give artificial milk supplements to all breast-fed infants during early maternal lactation, since the volume of mothers' milk, perhaps due to climatic conditions, tends to be insufficient at this time. About

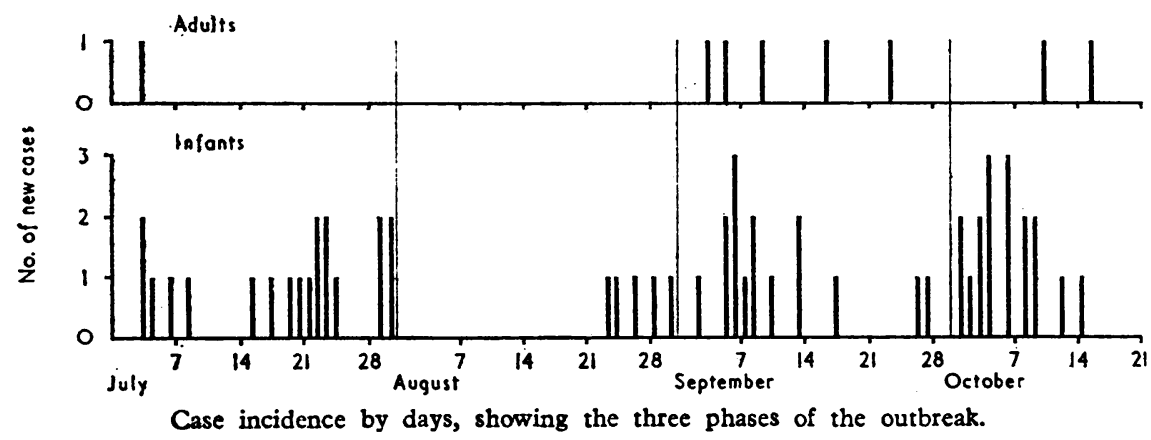

hospital. The majority of the mothers delivered were the wives of British and Commonwealth Servicemen; a few were wives of members of the Singapore armed Forces.

Between 4 July and 20 October 196656 newborn infants, seven mothers, and one nursing sister developed febrile illnesses with a variety of signs and symptoms. Of the 248 babies born during the 16 weeks of the outbreak two were stillborn and two died from causes unrelated to the epidemic. Thus 56 $(23 \%)$ of 244 healthy infants and $7(3 \%)$ of 247 mothers showed clinical signs of infection.

An equal number of male and female infants were affected; 55 were European and one was Asian. The ages of the infants at onset of the disease were from 2 to 12 days. The eight adults were all European and their ages ranged from 19 to 26 years. The pattern of the epidemic is illustrated in the Chart, which shows three distinct waves of infection with two intervening quiescent periods during which no fresh cases were observed.

\section{Clinical Features}

All 56 infants had pyrexia, which ranged from 99 to $105^{\circ} \mathrm{F}$. (37.2 to $40.6^{\circ} \mathrm{C}$.) ; in $49(87 \%)$ the temperature was in excess of $101^{\circ} \mathrm{F} .\left(38.3^{\circ} \mathrm{C}\right.$.) at some time during the illness. The onset of pyrexia was between the fourth and eighth days in $80 \%$ of the infants and its mean duration was 3.5 days, with a range of 2 to 7 days. half the affected infants were reluctant to feed and often vomited shortly after feeding. Most of them showed a slight loss of weight during the illness, but none required parenteral fluids. Two infants developed transient jaundice, but no definite cause was established.

A number of microbial infections were found in the affected infants ; there were 11 instances of oral thrush ; Staphylococcus aureus was isolated from two infants with umbilical sepsis and from one with conjunctivitis.

The illness in the eight adults, seven of whom were mothers of affected babies, began with malaise, fever, severe headache, and vomiting which lasted for one to two days. The temperature exceeded $101^{\circ} \mathrm{F}$. $\left(38.3^{\circ} \mathrm{C}\right.$.) in five patients, and pyrexia lasted between one and seven days, with a mean of five days. All developed a rash which was similar in appearance and distribution to that seen in the infants, but was more persistent. Two had upper respiratory tract symptoms and one had neck stiffness and myalgia. All 64 patients recovered completely; all the adults and 51 of the infants were known to be healthy with no sequelae one year after the illness.

* Squadron Leader, Royal Air Force. Consultant Obstetrician, R.A.F. Hospital, Changi, Singapore. Present address: Princess Mary's R.A.F. Hospital, Halton, Bucks.

+ Squadron Leader, Royal Air Force. Consultant Pathologist, R.A.F. Institute of Pathology and Tropical Medicine, Halton, Bucks. Present Institute of Pathology and Tropical Medicine, Hesicy address: Department of Pathology,

School, San Antonio, Texas, U.S.A. Virology, R.A.F. Institute of Pathology and Tropical Medicine, Halton, Bucks. 


\section{Virological Studies}

Faecal specimens were obtained for virus culture from the eight adults and from 30 infants during the first six days of their illness; most were obtained in the first three days. Where possible, acute and convalescent samples of serum were obtained from adult patients. Faeces and sera were stored at $-20^{\circ} \mathrm{C}$. and sent to England by air in wet ice held in vacuum containers which were replenished with ice en route. These specimens were received at the virus laboratory within $\mathbf{4 8}$ hours of dispatch from Singapore. Sera were also obtained from a number of the patients who were traced at periods from 9 to 12 months after the outbreak.

Standard virological methods were used (Busby et al., 1964 ; Lenette and Schmidt, 1964). Faecal extracts were prepared in Hanks's solution plus penicillin, streptomycin, and amphotericin $\mathrm{B}$, and were inoculated into stationary tubes of $\mathrm{HeLa}$ cells and roller tubes of cynomolgus or green monkey kidney cells. The tubes were observed daily up to 10 days for cytopathogenic effect. Litters of six suckling mice were inoculated subcutaneously and intracerebrally from pools of six faecal specimens and observed for 14 days. Negative or doubtful cultures were passaged a second time. The cytopathogenic effect of the enterovirus type was produced by 24 of the 38 faecal extracts on first passage and by a further seven extracts on second passage in monkey kidney cells. No changes were observed in the HeLa cell cultures, and the litters of mice remained healthy. On the basis of these findings a tentative diagnosis of E.C.H.O. virus disease was made and relayed to Singapore. The 31 viral isolates adapted on one further passage to a line of human embryo lung cells, in which they produced a rapid cytopathogenic effect in 24 to $\mathbf{4 8}$ hours. Further titration and typing procedures were carried out satisfactorily in this cell system despite reports of the low affinity of E.C.H.O. viruses for human embryonic lung cells (Lee et al., 1965). The viruses were confirmed as members of the enterovirus group by their resistance to diethyl ether, to heating to $56^{\circ} \mathrm{C}$. for 30 minutes in molar magnesium chloride, and to the action of 2 ( $\alpha$-hydroxybenzyl)-benzimidazole. All 31 viral isolates were neutralized by E.C.H.O. virus type 5 antisera (kindly supplied by the Virus Reference Laboratory, Colindale). No haemagglutination was demonstrable with human group $O$ or guinea-pig red cells at $4^{\circ}, 18^{\circ}$, or $37^{\circ} \mathrm{C}$.

Neutralizing antibodies to E.C.H.O. virus type 5 in acute and convalescent sera were assayed in green monkey kidney cells; eightfold to 64-fold rises in titre were found in the five paired sera obtained from infected mothers. Neutralization tests were carried out on sera obtained from infants and mothers 9 to 12 months after the outbreak (see Table). These indicate that there were a number of subclinical infections in mothers and infants and that fairly high levels of antibodies persisted for some time after the epidemic.

Neutralizing Antibodies to E.C.H.O. Virus Type 5 in Sera Obtained 9 to

\begin{tabular}{|c|c|c|c|c|}
\hline & \multirow{2}{*}{ Total } & \multirow{2}{*}{$\begin{array}{l}\text { No. } \\
\text { Teeted }\end{array}$} & \multicolumn{2}{|c|}{ No. with Titre } \\
\hline & & & $>1 / 40$ & $<1 / 40>1 / 10$ \\
\hline $\begin{array}{l}\text { Clinically affected infants } \\
\text { Normal infants } \\
\text { Clinically affected adulits } \\
\text { Normal mothers of affected } \\
\text { infahts }\end{array}$ & $\begin{array}{r}56 \\
188 \\
8 \\
49\end{array}$ & $\begin{array}{r}24 \\
21 \\
6\end{array}$ & $\begin{array}{r}15 \\
15 \\
6\end{array}$ & $\begin{array}{l}1 \\
1 \\
0\end{array}$ \\
\hline
\end{tabular}

\section{Discussion}

Outbreaks of illness due to enteroviruses are universal, but all reported epidemics of E.C.H.O. virus disease have occurred in temperate zones (Melnick, 1965). This outbreak, which occurred in a perennially hot climate, is therefore most unusual. E.C.H.O. virus type 5 has been reported from America and in
England in association with sporadic cases of aseptic meningitis (Davis and Melnick, 1958) and exanthematous disease (Selwyn and Howitt, 1962). In the small outbreak of E.C.H.O. virus type 5 infection described by Hart et al. (1962), which also occurred in a neonatal unit, fever, diarrhoea, splenomegaly, and lymphadenopathy were the main findings. The variety of signs and symptoms encountered during the present outbreak included the majority of those which have been associated with infections by all E.C.H.O. virus serotypes. A pink macular rash was among the commonest findings. This has been associated with E.C.H.O. virus type 5 infection (Selwyn and Howitt, 1962), but was not found in the infants described by Hart et al. (1962).

Diarrhoea was a common feature of this outbreak. The association of several serotypes of E.C.H.O. virus with enteritis has been reported by Ramos-Alvarez and Sabin (1958), Sommerville (1958), Eichenwald et al. (1958), and others. The presence of blood and mucus found in the stools of four of the infants described here has been reported in enteritis due to E.C.H.O. virus type 14 (Lepine et al., 1960). However, for the present it must remain doubtful whether diarrhoea is directly attributable to E.C.H.O. viruses, since Bell and Grist (1967) have drawn attention to the lack of evidence that enteroviruses are a significant cause of diarrhoea.

Symptoms of upper respiratory infection, which affected two adult patients, have been associated with a number of E.C.H.O. virus serotypes, including type 14 (Karzon et al., 1961), type 6 (Karzon et al., 1962), and type 9 (Landsman and Bell, 1962). None of the infants, however, had respiratory infections, nor had they any obvious evidence of involvement of the central nervous system which was possibly present in the adults.

Though the transient jaundice found in two of the infants may have been due to other causes, disturbance of liver function has occurred in infections with E.C.H.O. virus types 4 and 9 (Karzon et al., 1961 ; Sabin et al., 1958).

Because of the symptomatology, the relatively high rate of positive virus cultures, and the highly significant elevations of titre of neutralizing antibodies in five patients, and the persistent high levels of antibodies in many others, it seems reasonable to assume that the E.C.H.O. virus type 5 was the cause of this outbreak. As the source of the outbreak was not apparent, one can only speculate that the likeliest route of infection was via the mouth.

The early symptomatology and the extent of an epidemic such as this in a maternity unit will inevitably cause a great deal of concern pending the results of virological investigations. Isolation and identification of the causative agent can do much to allay this concern, though initially the clinician has to rely to a great extent on the interpretation of clinical findings to arrive at a tentative diagnosis of enterovirus infection. The prognosis in E.C.H.O. virus type 5 infection, as judged by this outbreak, is excellent, and this is in keeping with that in most E.C.H.O. virus infections.

\section{Summary}

An outbreak of febrile illness due to E.C.H.O. virus type 5 which affected 56 infants and eight adults in a maternity unit in Singapore is described. There was a wide range of signs and symptoms, all of which had been described previously for other E.C.H.O. virus serotypes. The epidemic lasted 16 weeks, but no serious maternal or neonatal complications occurred, nor were there any known late sequelae.

We wish to record our appreciation of the maternity nursing staff of R.A.F. Hospital, Changi, for the care of the mothers and babies involved in this outbreak, and of the laboratory staff for their efficient handling of the many clinical specimens. We are grateful to the Virus Reference Laboratory, Colindale, London, for typing the first virus isolate and for supplying neutralizing antisera. We thank Air Vice-Marshal W. P. Stamm and Group 
Captain K. R. Hudson for their helpful advice, and the Director General of Medical Services, Royal Air Force, for permission to publish.

\section{REFERENCES}

Bell, E. J., and Grist, N. R. (1967). Brit. med. f., 4, 741. Busby, D.' W. G., House, W., and MacDonald, J. R. (1964). Virological Davis, D. C., and Melnick, J. L. (1958). \%. Lab. clin. Med., 51, 97 Eichenwald, H. F., Abatio, A., Arky, A. M., and Hartman, A. P. (1958). 3. Amer. med. Ass., 166, 1563.

Hart, E. W., Brunton, G. B., Taylor, C. E. D., Maurice-Williams, F. E., and Coetzee, E F C. (1962). Lancet, 2, 402. and Coetze, E F C. (1962). Lancet, 2, 402.
Karzon, D. T., Eckert, G. L., Barron, A. L., Hayner, N. S., and
Winkelstein, W. (1961). Amer. F. Dis. Child., 101, 610.
Karzon, D. T., Hayner, N. S., Winkelstein, W., and Barron, A. L. (1962). Paediatrics, 29, 418.

Kibrick, S. (1964). Progress in Medical Virology, edited by J. L. Melnick, vol. 6. Basle and New York.

Landsman, J. B., and Bell, E. J. (1962). Brit. med. F., 1, 12.

Lee, L. H., Phillips, C. A., South, M. A., Melnick, J. L., and Yow, M. D '(1965). Bull. Wild Hlth Org., 32, 657.

Lenette, E. H., and Schmidt, N. J. (1964). Diagnostic Procedures for Viral and Rickettsial Diseases, 3rd ed. New York.

Lepine, P., Samaille, J., Maurin, J., Dubois, O., and Carre, M. C. (1960). Ann. Inst. Pasteur, 99, 161 .

Melnick, J. L. (1965). In Viral and Rickettsial Infections of Man, edited by F. I. Horsfall and I. Tamm, 4th ed., p. 536. London.

Ramos-Alvarez, M., and Sabin, A. B. (1958). F. Amer. med. Ass., 167,

Sabin, A. B., Krumbiegel, E. R., and Wigand, R. (1958). Amer. 7. Dis. Child., 96, 197.

Selwyn, S., and Howitt, L. F. (1962). Lancet, 2, 548.

Sommervilie, R. G. (1958). Lancet, 2, 1347.

\title{
Fatal Case of Gas Gangrene Associated with Intramuscular Injections
}

\author{
P. W. HARVEY,* V.R.D., M.B., CH.B., F.C.PATH., D.PATH. ; G. V. PURNELL, $\dagger$ M.B., CH.B.
}

Brit. med. F., 1968, 1, 744-746

This paper reports a case of fatal gas gangrene complicating a simple therapeutic injection of adrenaline mucate given in a hospital ward.

Touraine and Gautier (1936) went to considerable lengths to conceal the identity of their patient in a case similar to the one which we are reporting, and in all probability the fear of litigation has inhibited the publication of other reports. In fact, the description of this case has been delayed because a colleague originally vetoed publication. It should be emphasized that this patient died some years ago, in another place, and was in no way connected with the towns where either of us now practise.

The development of central sterile supply departments and the more recent introduction of disposable sterilized equipment have greatly reduced, but by no mean eliminated, the risk of infection, which can be introduced by injections (Cayton and Morris, 1966).

It is highly probable that the present patient would still have died even though the syringes and needles used to treat him had been prepared in accordance with the techniques employed now, many years after the tragedy.

\section{Case Report}

A 22-year-old man was admitted to hospital with severe status asthmaticus. During the first 18 hours treatment consisted of intravenous injections of aminophylline followed by intramuscular aminophylline, Hyperduric adrenaline, and Gardenal sodium (phenobarbitone sodium).

On the morning of the second day he was very much better, though he complained of some pain in the lower lumbar region and both buttocks. The consultant physician in charge of the case examined the patient, paying special attention to the buttocks, which had been the site of some of the intramuscular injections. He found no evidence of an inflammatory reaction or of focal tenderness. The patient's improvement was maintained throughout that day and evening, though he still complained intermittently of low back pain.

Early on the morning of the third day he became very restless and appeared to be ill. He was found to have acute peripheral circulatory failure, the blood pressure being unrecordable. There

- Consultant Pathologist, Royal Lancaster Infirmary.

+ Industrial Medical Officer, British Aircraft Corporation Limited, Preston. was a diffuse swelling over the right buttock and the lateral aspect of the upper third of the right thigh. Palpation of this swelling revealed obvious crepitus. Gas gangrene infection was diagnosed and the appropriate treatment instituted at 08.30 hours. This included intravenous anti-gas-gangrene serum, penicillin, and noradrenaline transfusions. Initially $1,000,000$ units of penicillin was given intramuscularly and 500,000 units intravenously.

One hour later the patient showed no evidence of response, so $200 \mathrm{mg}$. of hydrocortisone and a further 500,000 units of penicillin were added to a glucose drip. In spite of these measures he died at 12.30 hours-that is, four hours later. In retrospect, it is important to note that he had been incontinent of faeces on admission to the ward.

Necropsy was performed by Dr. G. B. Manning (Home Office pathologist) in our presence. The findings were of a classical gasgangrene infection which appeared to have arisen from a needle track 2 in. $(5 \mathrm{~cm}$.) long in the muscle of the right buttock. Subsequent histology confirmed the necropsy findings and also revealed a generalized septicaemia due to Gram-positive bacilli.

Gram-positive bacilli were cultured from the needle track and from subcutaneous tissue in the lumbar region as well as from the patient's faeces. The colonial appearances, the cultural characteristics, and the sugar and Nagler reactions of all three strains were identical and typical of Clostridium welchii.

The cultures were sent to the Central Serological Laboratory, London, for further investigation. The toxins produced by the three strains were identical and consisted of alpha, theta, and kappa toxins. The strains were therefore $\mathrm{Cl}$. welchii type $\mathrm{A}$.

Universal containers of Robertson's meat medium containing pure cultures of the organism were left on the bench for some months at room temperature. When the cultures were re-examined special stains confirmed that spores had formed. In due course sterile filter paper was impregnated with these spores and used for heatresistance tests.

\section{Literature}

The dangers of gas gangrene occurring in operating-theatres is generally recognized (Brit. med. Y., 1967), but it is less widely known that this infection can arise at the sites of intramuscular injections.

Mabin (1936) lists 84 cases, none of them in the English literature. The majority were reported from Germany and Italy and there were 10 cases from France. Further cases have since been published in the French literature by Touraine and Gautier (1936), Lagrot (1938), Brocard (1940), and Ramond 